ARTICLE

\title{
Boron isotopes in boninites document rapid changes in slab inputs during subduction initiation
}

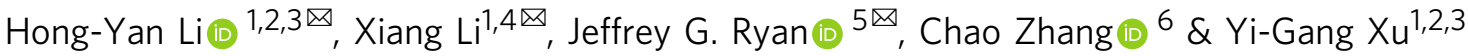

\begin{abstract}
How subduction-related magmatism starts at convergent plate margins is still poorly understood. Here we show that boron isotope variations in early-formed boninites from the Izu-Bonin arc, combined with radiogenic isotopes and elemental ratios document rapid ( 0.5 to $1 \mathrm{Myr}$ ) changes in the sources and makeup of slab inputs as subduction begins. Heterogeneous hornblende-granulite facies melts from ocean crust gabbros \pm basalts fluxed early melting to generate low silica boninites. Hydrous fluids from slab sediments and basalts later fluxed the low silica boninites mantle source to produce high silica boninites. Our results suggest that initially the uppermost parts of the slab were accreted near the nascent trench, perhaps related to early low-angle subduction. The rapid changes in slab inputs recorded in the boninites entail a steepening subduction angle and cooling of the plate interface, allowing for subduction of slab sediment and basalt, and generating hydrous fluids at lower slab temperatures.
\end{abstract}

\footnotetext{
${ }^{1}$ State Key Laboratory of Isotope Geochemistry, Guangzhou Institute of Geochemistry, Chinese Academy of Sciences, Guangzhou 510640, China. ${ }^{2}$ CAS Center for Excellence in Deep Earth Science, Guangzhou 510640, China. ${ }^{3}$ Southern Marine Science and Engineering Guangdong Laboratory (Guangzhou), Guangzhou 511458, China. ${ }^{4}$ University of Chinese Academy of Sciences, Beijing 100049, China. ${ }^{5}$ School of Geosciences, University of South Florida, Tampa, FL 33620, USA. ${ }^{6}$ State Key Laboratory of Continental Dynamics, Department of Geology, Northwest University, Xi'an 710069, China.

凶email: hongyanli@gig.ac.cn; lixiang@gig.ac.cn; ryan@usf.edu
} 
$\mathrm{D}$ espite over fifty years of studies into the workings of plate tectonics, the phenomenon of subduction initiation is still not well understood ${ }^{1-3}$. How slabs start to subduct, whether via shallow convergence ${ }^{4}$ or vertical foundering ${ }^{5,6}$, to the point that they begin to interact with the mantle continues to be debated. The Izu-Bonin-Mariana (IBM; Fig. 1) convergent plate margin is a unique natural laboratory for the study of subduction initiation, with well-preserved forearc igneous sequences that represent the first eruptive products of subduction in this region. International Ocean Discovery Program (IODP) Expedition 352 recovered a representative suite of the earliest subduction-related volcanic sequences of the Izu-Bonin subduction system ${ }^{7-9}$ (Fig. 1). Drillsites nearer the trench (U1440 and U1441) recovered forearc basalts (FAB), while two sites $\sim 15 \mathrm{~km}$ inboard from the trench (U1439 and U1442) recovered boninites and their high-Mg andesite (HMA) differentiates. Radiometric dates for FAB are 51.9-51.3 Myr, while boninite dating suggest eruption very shortly thereafter, at $\sim 51.3-50.3 \mathrm{Myr}^{7}$. On the JOIDES Resolution, the Expedition 352 science team used a hand-held portable XRF (pXRF) instrument to track chemical variations in the $\mathrm{FAB}$ and boninite sections as part of the core logging process, collecting over 2000 individual measurements ${ }^{10}$. Recent high precision shore-based XRF analyses ${ }^{11,12}$ supplemented by the shipboard $\mathrm{pXRF}^{10}$ and ICP-AES ${ }^{13}$ analyses created high resolution chemostratigraphies for the drilled holes ${ }^{10-13}$. In the boninite holes (U1439A, U1439C and U1442A), lavas < 250 meters below the seafloor (mbsf) are dominated by high silica boninites (HSB) and their HMA differentiates, while lavas $>250 \mathrm{mbsf}$ are dominated by low silica boninites (LSB) and HMA, with uncommon appearances of $\mathrm{HSB}^{12}$, consistent with HSB intrusions through LSB strata.

Boninites are a ubiquitous early IBM volcanic product, which requires that a chemically highly depleted, shallow mantle source be fluxed by the slab ${ }^{14}$. Expedition 352 boninites all have elevated $\mathrm{SiO}_{2}$ and $\mathrm{MgO}$, and low rare earth element (REE) contents, consistent with melting of highly depleted mantle ${ }^{4,12,14}$. The HSB have higher $\mathrm{SiO}_{2}$ and lower $\mathrm{TiO}_{2}$ at given $\mathrm{MgO}$ than the $\mathrm{LSB}^{9,12}$, pointing to more depleted mantle ${ }^{15}$. The IBM boninites show fluid-mobile element (FME) enrichments broadly similar to those in arc lavas, but are also enriched in key fluid-immobile species (e.g., $\mathrm{Zr}$ and $\mathrm{Hf}$ ) that suggest the involvement of slab-derived melts at relatively shallow depths ${ }^{16}$.

Trace element and radiogenic isotope results indicate little or no slab influence on the mantle sources of the earliest erupted Izu-Bonin $\mathrm{FAB}^{4,11,17}$. LSB lavas specifically and boninites more generally have been interpreted as reflecting slab melt contributions from Pacific plate crust ${ }^{4,16}$. Slab sediment-derived isotopic signatures only become evident in the later erupted $\mathrm{HSB}^{4}$. However, the specific constituents of the oceanic crust and lithosphere (altered basalts or gabbros, or lithospheric serpentinite) that contribute to boninite genesis, and the respective roles of slab-derived fluids and/or melts in the genesis of the HSB
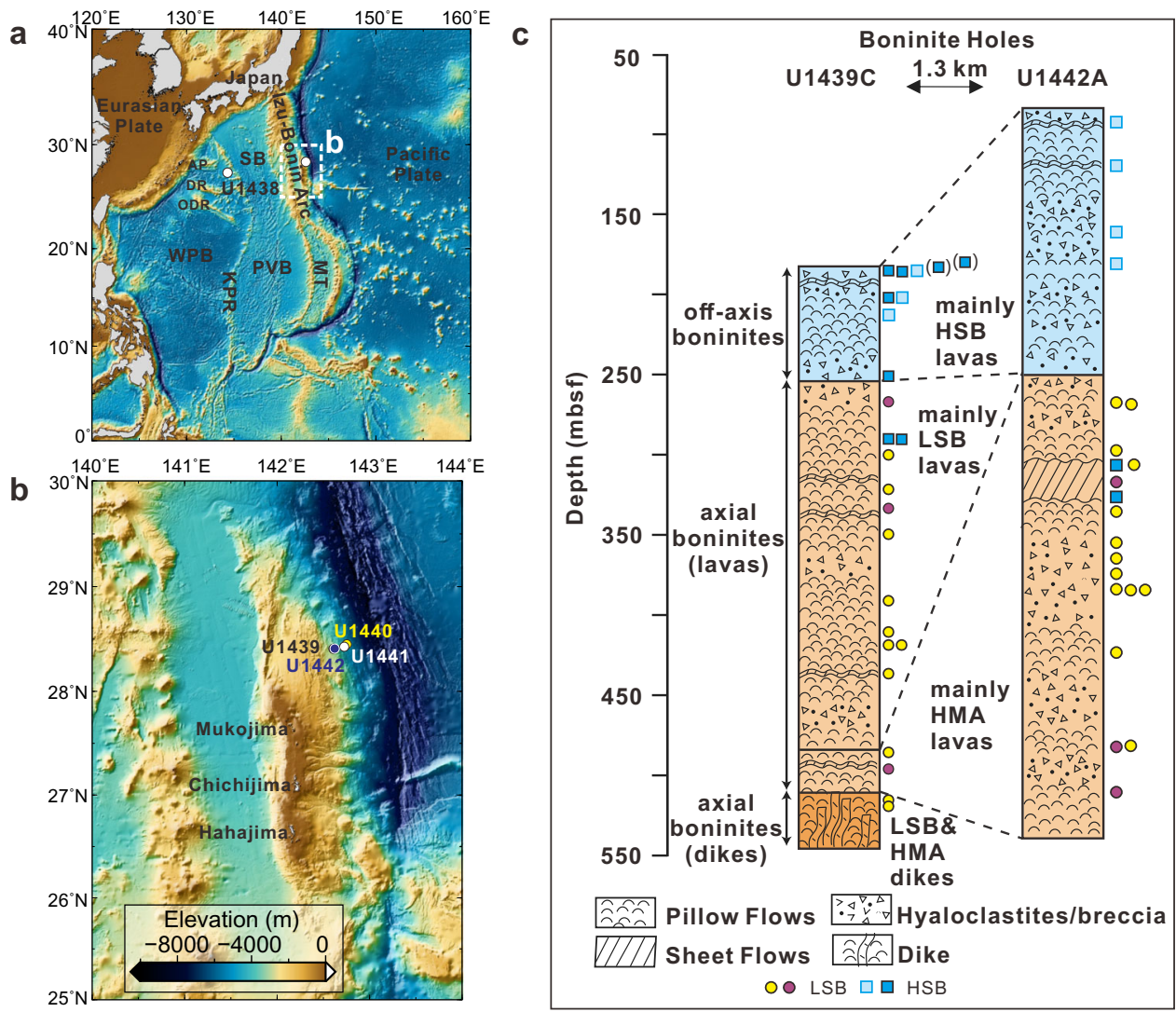

Fig. 1 Regional map of the Izu-Bonin-Mariana convergent plate margin with sampling locations. a, b Locations of the International Ocean Discovery Program Expedition 352 drill sites in the Izu-Bonin forearc, Western Pacific. U1439 and U1442 are boninite sites, while U1440 and U1441 are forearc basalt sites. c Simplified logs for the two boninite holes (U1439C and U1442A), recovering lavas and dykes mainly of high-silica (HSB) and low-silica (LSB) boninites and their differentiation products, high magnesium andesites (HMA). The depths in the cores for each sample examined this study and HSB samples from Li et al. ${ }^{4}$ (light blue squares) are plotted alongside the core logs. The depth of two HSB samples from hole U1439A (In brackets) are also plotted alongside hole U1439C. For the purposes of this study HMA differentiates are not distinguished from their parental HSB or LSB. SB: Shikoku Basin; PVB: Parece Vela Basin; MT: Mariana Trough; KPR: Kyushu Palau Ridge; WPB: West Philippine Basin; AP: Amami Plateau; DR: Daito Ridge; ODR: Oki-Daito Ridge; mbsf: meters below the seafloor. 
versus the LSB are still not well understood. These questions are directly relevant to how forearc magmatism reflects the geometry of the downgoing slab and its thermal evolution during the subduction initiation. Of particular importance in this regard is constraining the slab-to-mantle inputs during subduction initiation, and the mechanisms governing them. The extremely depleted nature of boninite mantle sources means that even minor inputs from the downgoing plate should produce strong geochemical signals. Boron (B), as an endmember trace element in terms of its extreme mobility off slabs, with clear abundance and isotopic differences among different slab constituents ${ }^{18,19}$, has great potential for tracking these earliest slab-to-mantle material exchanges.

Here, with new high precision $\mathrm{B}$ abundance and $\mathrm{B}$ isotope results, combined with data for other trace elements and with SrNd-Hf isotopes for Expedition 352 boninites, we show that rapid temporal changes occur in the slab inputs to the sources of IBM boninitic magmas, from melts of lower crustal gabbros to fluids derived from upper crustal basalts and sediments, which provides insights into the thermal evolution of the slab during the earliest stages of subduction.

\section{Results}

Boron elemental and isotopic compositions of the boninites. Boron concentrations in Expedition 352 boninites vary by boninite type, with mean LSB at $\approx 4 \mu \mathrm{g} / \mathrm{g} \mathrm{B}$, and mean HSB at $\approx 12 \mu \mathrm{g} / \mathrm{g}$ $B$ (Supplementary Data 1). While the B concentration ranges of HSB and LSB show some overlap, there are clear distinctions with respect to $\mathrm{MgO}$ and $\mathrm{TiO}_{2}$, suggesting multiple magmatic sequences with distinct $\mathrm{B}$ abundances. Differences in the correlations of $\mathrm{B}$ with $\mathrm{Ba}$ and other trace elements suggest LSB versus HSB source differences (Fig. 2). As $\mathrm{B}, \mathrm{Ba}$, and $\mathrm{Nb}$ are all strongly incompatible during mantle melting and magma chamber crystallization, $\mathrm{B} / \mathrm{Nb}$ and $\mathrm{Ba} / \mathrm{Nb}$ can characterize to a first order the degree of $\mathrm{B}$ and $\mathrm{Ba}$ enrichment in the mantle source. $\delta^{11} \mathrm{~B}$ in Expedition 352 boninites ranges from $-1.6 \%$ to $+8.3 \%$, with clear differences among sub-suites when linked to $\mathrm{B} / \mathrm{Nb}$ and $\mathrm{Ba} /$ $\mathrm{Nb}$ (Fig. 3a, b). The LSB encompass the full range of boninite $\delta^{11} \mathrm{~B}$ variation, and show variable $\mathrm{B} / \mathrm{Nb}$ and $\mathrm{Ba} / \mathrm{Nb}$. By contrast, $\delta^{11} \mathrm{~B}$ in the HSB cluster tightly between $-0.2 \%$ and $+1.8 \%$, and have uniformly higher $\mathrm{B} / \mathrm{Nb}$ and $\mathrm{Ba} / \mathrm{Nb}$. All $\mathrm{HSB}$, both those recovered at $<250 \mathrm{mbsf}$ and the few that crosscut LSB strata at $>250 \mathrm{mbsf}$, show closely similar geochemical characteristics, pointing to similar subduction inputs. The LSB appear to break into high and low $\mathrm{Ba}(\mathrm{Ba} / \mathrm{Nb})$ subgroups, based on correlations between $\mathrm{Ba}$ and $\mathrm{Nb}, \mathrm{Hf}, \mathrm{Zr}$, and Th (Supplementary Fig. S1 and Fig. 4a). No obvious stratigraphic relationships are evident among the LSB subgroups (Fig. 1c). The high-Ba/Nb LSB subgroup has an overall higher $\delta^{11} \mathrm{~B}(+0.5 \%$ o to $+8.3 \%$ o $)$ than do low-Ba/Nb LSB $(-1.6 \%$ o to $+4.1 \%$ ). The $\delta^{11} \mathrm{~B}$ of Expedition 352 boninites overall are lower than the $\delta^{11} \mathrm{~B}$ range reported for Izu-Bonin-Mariana arc volcanics $\left(\delta^{11} \mathrm{~B}:+3 \% \text { o to }+12 \%\right)^{20-22}$. In detail, the LSBs, in particular those with elevated $\mathrm{Ba} / \mathrm{Nb}$, show considerable $\delta^{11} \mathrm{~B}$ overlap with Izu-Bonin volcanic front lavas, while the low $\mathrm{Ba} / \mathrm{Nb}$ LSBs and all $\mathrm{HSB}$ are distinctly lower at $\mathrm{Ba} / \mathrm{Nb}$ ratios $2-20$ times lower than are seen in the arc. While the LSB range to higher $\delta^{11} \mathrm{~B}$, they have lower and more uniform ${ }^{87} \mathrm{Sr} /{ }^{86} \mathrm{Sr}(0.7032-0.7038)$ than the HSB (0.7035-0.7048; Fig. 3c).

Boron systematics in subduction versus subduction initiation settings. The model for B and B isotope systematics in arc magmatism is distinct among those of lithophile trace elements in that $\mathrm{B}$ is uniquely mobile in hydrous slab-derived fluids at low temperatures. Thus, slab-related reservoirs produced at low temperatures, specifically serpentinites derived ultimately from reactions with seawater (at $4.5 \mathrm{ppm} \mathrm{B}$ and $\delta^{11} \mathrm{~B} \approx+39.5 \%$ ) play an outsized role in $\mathrm{B}$ cycling during subduction, serving as both the dominant $\mathrm{B}$ reservoir, and the "best fit" source for the isotopically heavy $\delta^{11} \mathrm{~B}$ signatures seen in many arcs ${ }^{18,19,23}$. The involvement of serpentinites in arc magmatism is possible because in mature subduction systems downgoing plates often have sufficiently cool thermal structures to permit the deep subduction of serpentinite along the plate interface and within the uppermost portions of slab crust and lithosphere, leading ultimately to $\mathrm{B}$ enriched, high $\delta^{11} \mathrm{~B}$ eruptive products in arcs. By contrast, in subduction systems where downgoing plates are hotter and, usually, younger (e.g., the Cascades, Mexico, Italy), lavas are much less $\mathrm{B}$-enriched, and often preserve low $\delta^{11} \mathrm{~B}$ signatures suggesting little to no involvement of serpentinite in the slab-derived component ${ }^{18}$.

Subduction initiation as recorded in the IBM system ${ }^{24}$ reflects uniquely high temperature, low pressure conditions ${ }^{25}$, as initial slab foundering led to extension, asthenospheric upwelling and melting, resulting first in FAB magmatism and then boninite magmatism, all occurring in close proximity to the slab edge, such that shallow, hot mantle depleted by FAB melting was re-melted due to fluxing by slab-derived inputs $4,12,13,16$. Hot mantle conditions near the sinking edge of the downgoing plate are likely responsible for the generation of melts in the slab crust, suggested to occur under hornblende-bearing granulite facies conditions $\left(900-950{ }^{\circ} \mathrm{C}^{16,26}\right)$. Serpentine minerals break down at $<700^{\circ} \mathrm{C}$ under low-pressure conditions, and serpentinite decomposition will release water, which can cause ocean crust to melt at low temperatures $\left(<750^{\circ} \mathrm{C}^{26}\right)$. Therefore, slab-hosted serpentinites (either crustal or lithospheric) must have been scarce for the slab to reach higher temperatures before melting to fertilize the boninite mantle source. It is unlikely that serpentinites could develop in a nascent subduction interface, given the high temperature conditions. If they ever existed, they would be likely to break down well before slab melts could be generated.
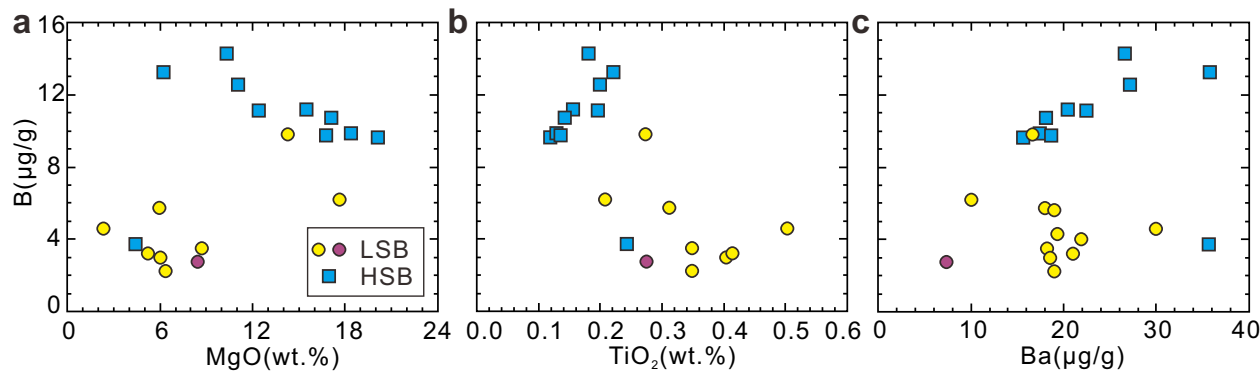

Fig. 2 Boron elemental variations of the Expedition 352 boninites. Plots of $\mathrm{B}$ vs. a MgO, $\mathbf{b} \mathrm{TiO}_{2}$ and $\mathbf{c}$ Ba for the Expedition 352 boninites. LSB: low-silica boninite; HSB: high-silica boninite. 

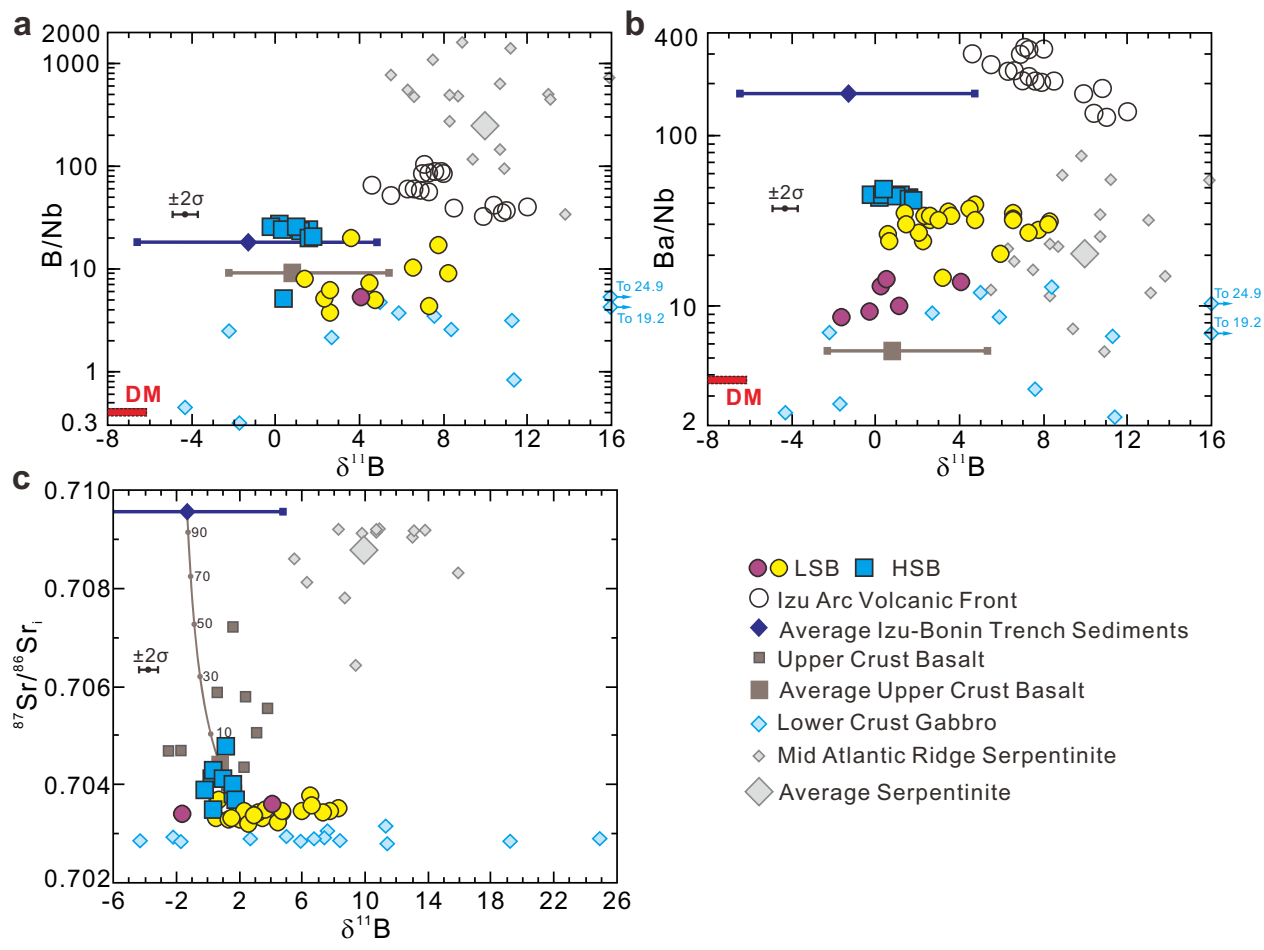

Izu Arc Volcanic Front

Average Izu-Bonin Trench Sediments

- Upper Crust Basalt

Average Upper Crust Basalt

$\diamond$ Mid Atlantic Ridge Serpentinite

Average Serpentinite

Fig. 3 Boron and strontium isotopes and trace element systematics of the Expedition 352 boninites. Plots of a B/Nb, b Ba/Nb and $\mathbf{c}{ }^{87} \mathrm{Sr} /{ }^{86} \mathrm{Sr} r_{i} v s . \delta^{11} \mathrm{~B}$ for the International Ocean Discovery Program Expedition 352 boninites. Error bars $\left(2 \sigma=0.6 \%\right.$ ) for boninite $\delta^{11} \mathrm{~B}$ represent average whole chemical process external reproducibility based on duplicate analyses of different digestion of the reference materials and natural samples ${ }^{62}$. Depleted mid-ocean ridge basalt mantle (DM ${ }^{32,49,64}$ ), Mid-Atlantic Ridge serpentinites ${ }^{65}$, Izu-Bonin trench sediment ${ }^{28,38,39}$, upper crust basalts (Deep Sea Drilling Project Holes 417A, 417D and 418A)28,66, lower crust gabbros (Ocean Drilling Program Hole 735B)28,54, and Izu arc (Ocean Drilling Program Hole 782A tephra) 21 data are shown for comparison. Bulk mixing curve between Izu-Bonin trench sediment and upper crust basalt in $\mathbf{c}$ is calculated per their chemical compositions, summarized in Supplementary Table 1. Numbers on the mixing curves denote percentages. Two low-silica boninite (LSB) subgroups are distinguished by their distinct $\mathrm{Ba}$ versus $\mathrm{Nb}, \mathrm{Zr}, \mathrm{Hf}$, and Th correlations (Supplementary Fig. 1). HSB: high-silica boninite.

Slab sources for boninite boron in subduction initiation settings. Although $\delta^{11} \mathrm{~B}$ data for ocean crust are limited, there nonetheless appear to be distinctions in $\delta^{11} \mathrm{~B}$ with crustal layer ${ }^{27-29}$ : oceanic Layer $2 \mathrm{a}$ basalts and diabases vary from $-2.5 \%$ o to $+5.4 \%$, while gabbroic Layer 3 rocks scatter from $-4 \%$ o to $+25 \%$, with consistently lower $\mathrm{B} / \mathrm{Nb}$ and overall higher $\delta^{11} \mathrm{~B}$ than Layer $2 \mathrm{a}$ altered basalts ${ }^{28}$ (Fig. 3). Similar patterns have also been observed in ophiolitic crustal sections ${ }^{30,31}$. Layer $2 \mathrm{a}$ and Layer 3 are also distinguishable in terms of Sr isotopes, with Layer 3 rocks preserving consistently lower ${ }^{87} \mathrm{Sr} /{ }^{86} \mathrm{Sr}$ than Layer $2 \mathrm{a}$ rocks. The combined $\mathrm{B}$ and $\mathrm{Sr}$ isotopic systematics of oceanic Layer 3 rocks are consistent with overall lower extents of seawater alteration than seen in Layer $2 \mathrm{a}$, leading to lower ${ }^{87} \mathrm{Sr} /{ }^{86} \mathrm{Sr}$ and lower B contents; and with exchanges occurring at overall higher temperatures than in Layer $2 \mathrm{a}$, consistent with greater depth in the crust, resulting in overall higher $\delta^{11} \mathrm{~B}$. The $\delta^{11} \mathrm{~B}$ variability in Layer 3 data points to considerable local variation in the extent of seawater/rock exchange deeper in the ocean crust, and to the extreme sensitivity of $\mathrm{B}$ isotopes to high $\mathrm{B}$, high $\delta^{11} \mathrm{~B}$ inputs (seawater at $4.5 \mathrm{ppm} \mathrm{B}$ and $\delta^{11} \mathrm{~B} \approx+39.5 \%$, as compared to fresh Layer 3 rocks at $<<1 \mathrm{ppm} \mathrm{B}$ and $\delta^{11} \mathrm{~B} \approx-7 \%{ }^{19,32}$ ).

Ocean crust metamorphic processing during subduction modifies its mobile element abundances and $\delta^{11} \mathrm{~B}$. In mature subduction zones, the $\delta^{11} \mathrm{~B}$ of the altered oceanic crust near the slab-mantle interface decreases due to early losses of high $\delta^{11} \mathrm{~B}$ boron to the forearc mantle at shallow depth, as indicated by $\delta^{11} \mathrm{~B}$ of $-6 \pm 4 \%$ of mafic blueschist clasts metamorphosed at $\sim 19 \mathrm{~km}$ depths and $200-350{ }^{\circ} \mathrm{C}$, recovered from serpentinite muds in the Mariana forearc ${ }^{33}$. However, during subduction initiation, the downgoing tip of the slab reaches much higher temperatures, upwards of $\sim 900^{\circ} \mathrm{C}$ at $1 \mathrm{GPa}$ based on recent models ${ }^{25}$. B, Rb, K, and $\mathrm{Ba}$ concentrations are high in amphibolites in the metamorphic sole of the Oman ophiolite, suggesting exchanges with FME-rich fluids during prograde slab metamorphism ${ }^{34}$. The Oman amphibolites have elevated $\delta^{11} \mathrm{~B}$, between $-2.3 \%$ to $+10.8 \%$, averaging $+3.75 \%{ }^{35}$. Exchanges with deeply derived amphibolite-facies fluids appear to explain high $\delta^{11} \mathrm{~B}$ signatures and elevated $\mathrm{B} / \mathrm{Nb}, \mathrm{Ba} / \mathrm{Nb}$ and $\mathrm{Sr} / \mathrm{Nd}$ in the Oman amphibolites, and this high temperature phenomenon may be characteristic of subduction initiation generally ${ }^{34}$. It is also possible that the breakdown of lithospheric serpentinite underlying downgoing plate crust could enrich crustal rocks with high $\delta^{11} \mathrm{~B}$ boron in similar ways, though serpentinites underlying the oceanic crust may be comparatively less enriched in B than crustal amphibolites, given the strong uptake of seawater-derived B during alteration of the oceanic crust ${ }^{27,36}$. Both amphibolite and serpentinite fluids will heat up when rising, increasing extraction of FMEs from the crust ${ }^{34,37}$. So generally, Layer $2 \mathrm{a}$ and Layer 3 ocean crustal materials can both provide heavy B during subduction initiation.

Modern marine sediments are enriched of $\mathrm{B}$, with Izu-Bonin trench sediments averaging $94.2 \mu \mathrm{g} / \mathrm{g} \mathrm{B}^{38}$, and the majority of analyzed samples ranging between 70 and $130 \mu \mathrm{g} / \mathrm{g}^{39}$. Sediment $\delta^{11} \mathrm{~B}$ ranges from -6.6 to $+4.8 \%$ with significant differences among constituents, e.g., continental detritus are very low, at -13 to $-8 \%$ while biogenic carbonates vary from +8.0 to $+26.2 \%{ }^{39}$. The majority $(>70 \%)$ of sediment-hosted B will likely be removed from sediments early in subduction by a range of fluid release phenomena, driven by mechanical compaction, diagenesis and prograde metamorphism, all at pressures $<1 \mathrm{GPa}$ and 

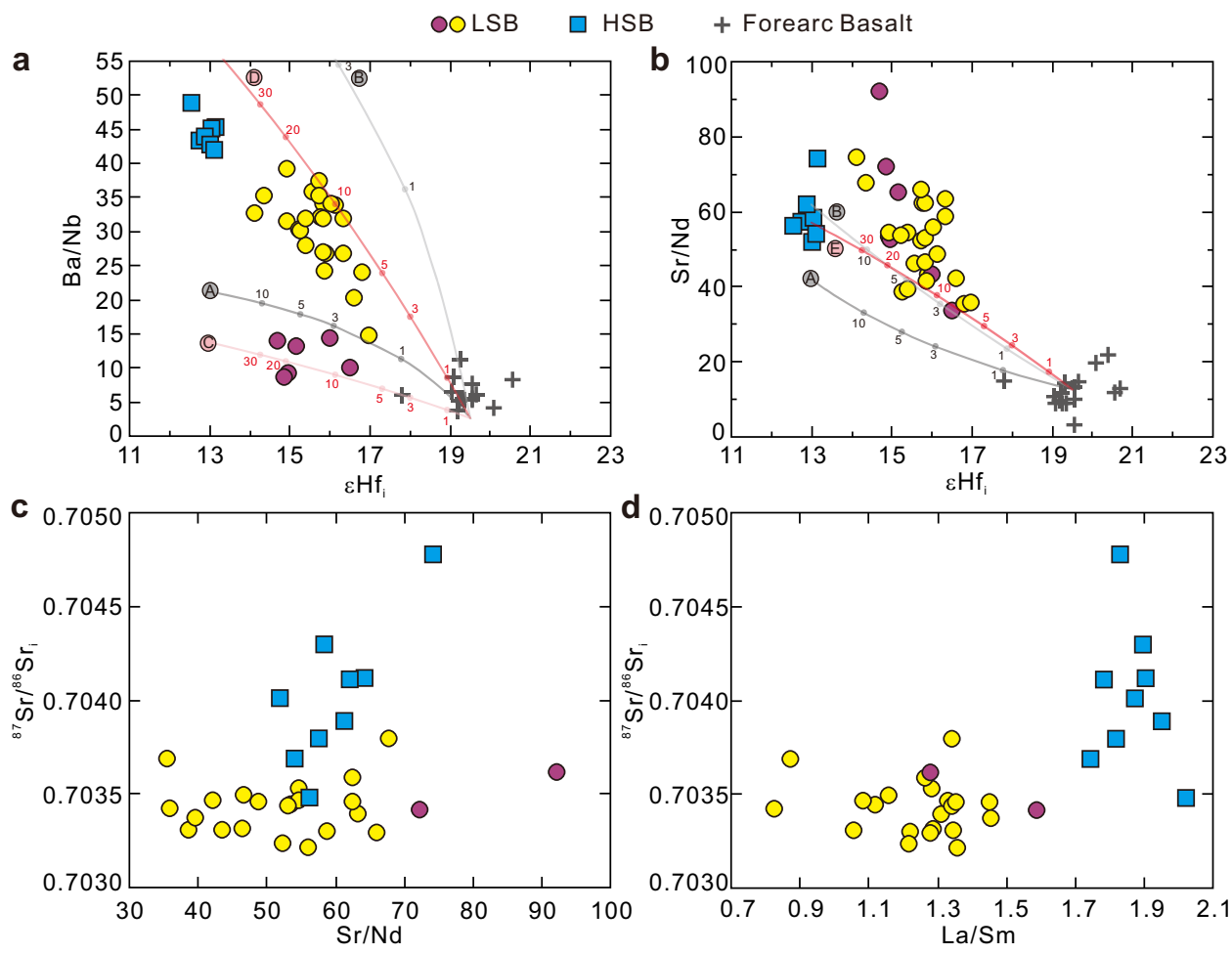

Fig. 4 Radiogenic isotopes and trace element systematics of the Expedition 352 boninites. Plots of a Ba/ $\mathrm{Nb}$ and $\mathbf{b} \mathrm{Sr} / \mathrm{Nd}$ versus $\varepsilon \mathrm{Hf} \mathrm{f}_{\mathrm{i}}$ and ${ }^{87} \mathrm{Sr} / 86 \mathrm{Sr}_{\mathrm{i}}$ versus c Sr/Nd and $\mathbf{d} \mathrm{La} / \mathrm{Sm}$ for International Ocean Discovery Program Expedition 352 forearc basalt and boninites. The mixing curves in a and $\mathbf{b}$ are between the depleted mid-ocean ridge basalt mantle 49,64 and the calculated granulite melts $(F=\sim 10 \%)$. A: Basaltic protolith low Ba/Nb granulite melts; B: Basaltic protolith high Ba/Nb granulite melts; C: Gabbroic protolith low Ba/Nb granulite melts; $\mathbf{D}$ : Gabbroic protolith high Ba/Nb granulite melts; E: Melts of gabbroic protolith granulite with its original $\mathrm{Sr} / \mathrm{Nd}$. The numbers on the mixing curves represent the mass percentage of the slab melt. The forearc basalt data are from Li et al. ${ }^{4}$. LSB: low-silica boninite; HSB: high-silica boninite.

temperature $<350^{\circ} \mathrm{C}$ in mature subduction zones ${ }^{40-44}$. Subducted sediments at $\sim 0.5 \mathrm{GPa}$ and $\sim 300^{\circ} \mathrm{C}$ should thus have lower $\mathrm{B}$ abundances $(3.4$ to $57.4 \mu \mathrm{g} / \mathrm{g})$ and lower $\delta^{11} \mathrm{~B} \quad(-9 \%$ to $-11.9 \%)^{45}$ than seafloor sediments. Similarly low B contents (3.6 to $24.1 \mu \mathrm{g} / \mathrm{g}$ ) are observed in subducted sediments from the Oman metamorphic sole ${ }^{34}$. Therefore, subducted sediments should generate isotopically light $\mathrm{B}$ inputs during subduction initiation.

Expedition 352 volcanic rocks show $\mathrm{Hf}, \mathrm{Nd}$ and $\mathrm{Pb}$ isotopic evidence for a shift from predominantly Indian Ocean-related mantle sources in early-erupted FAB to sources with a Pacific Ocean provenance in the boninites, consistent with slab-derived inputs from Pacific plate crust and lithosphere ${ }^{4}$. Our data patterns in Fig. 3 are consistent with these arguments, but provide more detail as to the likely source contributors. A key feature of our boninite data is the absence of any positive correlation between $\mathrm{B}$ enrichment and $\delta^{11} \mathrm{~B}$ : the HSB, which have the highest $\mathrm{B} / \mathrm{Nb}$ ratios, are among the lowest $\delta^{11} \mathrm{~B}$ lavas, while the LSB show variable $\mathrm{B} / \mathrm{Nb}$ ratios and $\delta^{11} \mathrm{~B}$ signatures, ranging from $\delta^{11} \mathrm{~B}$ lower than any HSB to $\delta^{11} \mathrm{~B}>+8 \%$. These systematics argue against a controlling role for a high $\mathrm{B}$, high $\delta^{11} \mathrm{~B}$ slab constituent such as serpentinite. In Fig. 3, our boninite data lie within the fields for Layer $2 \mathrm{a}$ and 3 ocean crustal rocks, and are largely distinct from the fields for serpentinites, and for Izu-Bonin arc lavas. The LSB show on average higher $\delta^{11} \mathrm{~B}$ at lower $\mathrm{B}$ enrichments and lower ${ }^{87} \mathrm{Sr} /{ }^{86} \mathrm{Sr}$, consistent with the signatures of Layer 3 crustal rocks. The LSB mantle source can best be explained by the involvement of contributions from subducted Layer 3 gabbros \pm less altered Layer 2a basalts, in consideration of metamorphism effects during subduction initiation. By contrast, HSB mantle sources appear to be more consistent with contributions from subducted sediments and/or altered Layer 2a basalt.

Basalt/gabbro melt inputs to the low silica boninite mantle source. Pearce et al. ${ }^{16}$ and $\mathrm{Li}$ et al. ${ }^{4}$ proposed melt inputs from subducting ocean crust with hornblende largely presented as residual mineral phase to explain decreases in $\varepsilon \mathrm{Hf}_{\mathrm{i}}$ and enrichments of $\mathrm{Zr}$ and $\mathrm{Hf}$ in the $\mathrm{LSB}$, as $\varepsilon \mathrm{Hf}_{\mathrm{i}}$ correlates positively with measures of $\mathrm{Hf}$ enrichment (e.g., Sm/Hf and Ti/Hf). As shown in Fig. $4 \mathrm{a}, \mathrm{b}, \mathrm{Ba} / \mathrm{Nb}$ and $\mathrm{Sr} / \mathrm{Nd}$ in the low- and high-Ba LSB subgroups show inverse correlations with $\varepsilon \mathrm{Hf}_{\mathrm{i}}$. The subgroups have distinctly different $\mathrm{Ba} / \mathrm{Nb}$ and overlapping, but different $\delta^{11} \mathrm{~B}$ ranges, and they are not discriminated by $\mathrm{Sr} / \mathrm{Nd}$ ratios. The patterns in Fig. 4 suggest that the systematics of $\mathrm{B}, \mathrm{Ba}, \mathrm{Sr}$ and $\mathrm{Hf}$ are broadly similar during the formation of the LSB. As Hf is uniformly immobile in hydrous fluids, correlations among these tracers mean that $\mathrm{B}, \mathrm{Ba}, \mathrm{Sr}$, and $\mathrm{Hf}$ must have been added to LSB sources via the same non-fluid slab input mechanism. Neither altered basalts nor sediments are a satisfactory source for this LSB slab component, as both have much higher ${ }^{87} \mathrm{Sr} /{ }^{86} \mathrm{Sr}$ (Fig. 3c), as well as more enriched $\mathrm{Pb}$ isotopes ${ }^{4}$. Less altered basalt and/or gabbro-derived amphibolites from deeper in the ocean crust are the most reasonable slab constituent to contribute to the LSB mantle source.

That our LSB data in Fig. 4a includes low- and high- $\mathrm{Ba} / \mathrm{Nb}$ subgroups likely points to the occurrence of multiple fluxing slab input events, each with different $\mathrm{Ba} / \mathrm{Nb}$ signatures and different $\delta^{11} \mathrm{~B}$ (Fig. 5). While the range in $\delta^{11} \mathrm{~B}$ in the low and high $\mathrm{Ba} / \mathrm{Nb}$ subgroups shows substantial overlap, lower $\delta^{11} \mathrm{~B}$ in the low $\mathrm{Ba} / \mathrm{Nb}$ samples is consistent with inputs from basalts/gabbros that have 

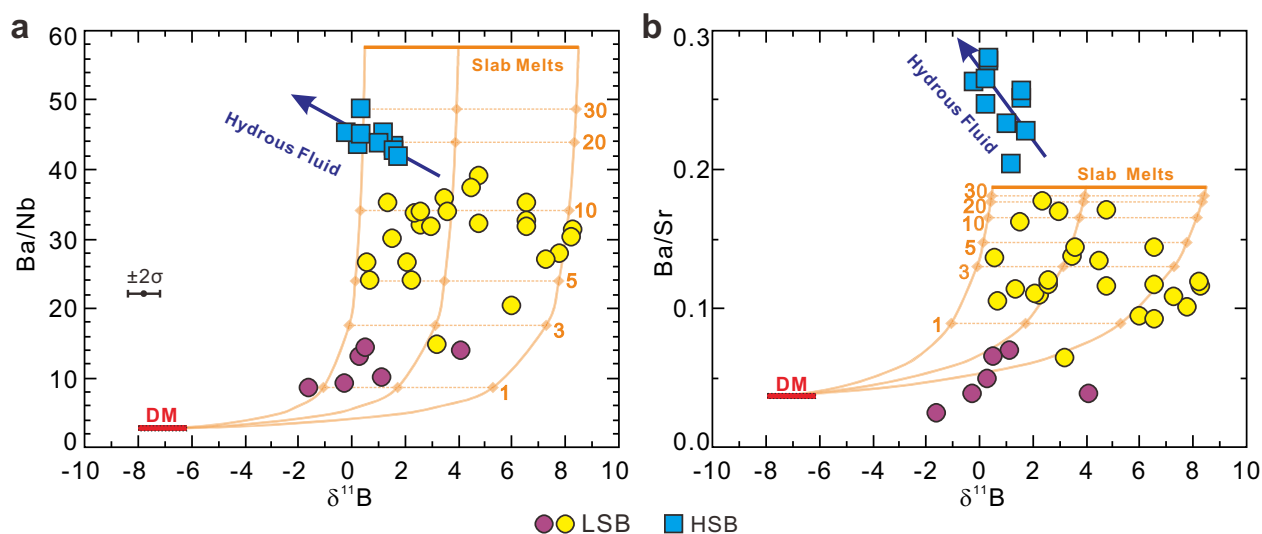

Fig. 5 Boron isotopes and trace element systematics of the Expedition 352 boninites compared to mixing trajectories between the calculated slab melt/fluid and the depleted mantle. Plots of $\mathbf{a ~ B a / N b}$ and $\mathbf{b} \mathrm{Ba} / \mathrm{Sr}$ vs. $\delta^{11} \mathrm{~B}$ for the International Ocean Discovery Program Expedition 352 boninites. Error

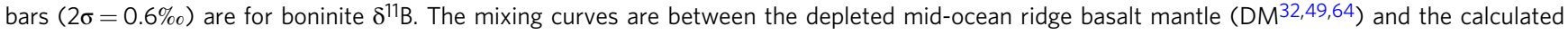
gabbroic protolith granulite melts. The numbers on the mixing curves represent the mass percentage of the slab melt. The $\delta^{11} \mathrm{~B}$ of the gabbroic protolith granulite melts are assumed to be from $+0.5 \%$ o to $+8.5 \%$. LSB: low-silica boninite; HSB: high-silica boninite.

suffered less metasomatism before melting. We have calculated trace element abundances for mineral-melt assemblages of representative amphibolite samples from the slab-mantle interface beneath the Oman ophiolite, one with high and one with low $\mathrm{Ba} / \mathrm{Nb}$ (samples WT28A-5 and WT32 $2^{34}$ ), under hornblendebearing granulite facies of $900^{\circ} \mathrm{C}$ and $0.9 \mathrm{GPa}$. This temperature is slightly higher than the reported peak metamorphic temperature of $\sim 825^{\circ} \mathrm{C}$ beneath the Oman ophiolite ${ }^{46}$ but is consistent with recent modeling by Zhou and Wada ${ }^{25}$. The chosen pressure is comparable to the highest equilibrium pressure estimates for LSB genesis $\left(0.4-0.9 \mathrm{GPa}^{12}\right)$. The calculations were performed using Perple_X $\mathrm{X}^{47}$ : detailed input parameters and outputs are provided in Supplementary Information. B-Ba-Nb-Sr-Nd-Hf abundances in the hornblende-bearing granulite melts $(\mathrm{F}=\sim 10 \%)$ were calculated from estimated mineral-melt assemblages, and the $\mathrm{Nb}, \mathrm{Nd}$, and $\mathrm{Hf}$ abundances of the "super composite" composition of ODP Site $801^{48}$. B, Ba, and $\mathrm{Sr}$ compositions were scaled to the $\mathrm{B} / \mathrm{Nb}, \mathrm{Ba} / \mathrm{Nb}$, and $\mathrm{Sr} / \mathrm{Nd}$ of representative Oman amphibolites (Supplementary Table S1). Detailed mineral-melt partition coefficients for the elements of interest are listed in Supplementary Table S2. Mixing arrays between the hornblende-bearing granulite melts and the depleted mantle (depleted DMM of Workman and $\mathrm{Hart}^{49}$ ) were also calculated assuming $\varepsilon \mathrm{Hf}=13$ for the granulite melts and $\varepsilon \mathrm{Hf}=19.5$ for the depleted mantle (Fig. 4a, b). Our calculations indicate that 1-10 wt.\% melt inputs from basaltic protolith granulites with high and low $\mathrm{Ba} / \mathrm{Nb}$ can explain the $\mathrm{Ba} / \mathrm{Nb}-\varepsilon \mathrm{Hf}$ variations for the two LSB subgroups, but do not explain the $\mathrm{Sr} /$ $\mathrm{Nd}$ versus $\varepsilon \mathrm{Hf}$ variations, as $\mathrm{Sr} / \mathrm{Nd}$ is too low (Fig. $4 \mathrm{~b}$ ).

We have also calculated melt compositions derived from hornblende-bearing granulite with gabbroic protoliths, using the average gabbro composition of the Atlantis Bank Massif (IODP Hole U1473A, SW Indian Ridge ${ }^{50}$; Supplementary Table S1), scaled to the $\mathrm{B} / \mathrm{Nb}$ and $\mathrm{Ba} / \mathrm{Nb}$ variation seen in Oman metamorphic sole amphibolites. Inputs of melts (3-20 wt.\%) from granulites with oceanic gabbro protoliths generally explain the $\mathrm{Ba} / \mathrm{Nb}$ versus $\varepsilon \mathrm{Hf}$ variations of the two subroups of LSB (Fig. 4a). More depleted mantle compositions require smaller percentage melt inputs ${ }^{12}$. $\mathrm{Sr} / \mathrm{Nd}$ ratios of gabbro-derived granulites are difficult to estimate. Assuming $\mathrm{Sr} / \mathrm{Nd}$ ratios similar to their protoliths (average $\sim 48^{50}$ ), the generated melts will have $\mathrm{Sr} / \mathrm{Nd}$ comparable to that of basalt-derived high $\mathrm{Ba} / \mathrm{Nb}$ granulite melts (Fig. 4b). Thus, melt inputs from gabbroic protolith granulites, modified by metamorphic fluids with elevated $\mathrm{Ba} / \mathrm{Nb}$ and $\mathrm{Sr} / \mathrm{Nd}$, may best explain the chemistry of the LSB.

Figure 5 compares our LSB data to calculated mixing arrays between depleted mantle and hydrous melts of lower crust gabbros under hornblende-bearing granulite facies conditions. As the LSB at $\mathrm{Ba} / \mathrm{Nb}>30$ have a wide range of $\delta^{11} \mathrm{~B}, \mathrm{~B}$ isotope heterogeneity is necessary in the crustal melt inputs. A hornblende granulite melt component with $\delta^{11} \mathrm{~B}$ between $+0.5 \%$ and $+8.5 \%$ best fit the $\mathrm{Ba} / \mathrm{Nb}$ and $\mathrm{Ba} / \mathrm{Sr}$ versus $\delta^{11} \mathrm{~B}$ patterns of the high $\mathrm{Ba} / \mathrm{Nb}$ subgroup LSB (Fig. 5). At $900^{\circ} \mathrm{C}$, crustal melting could induce at most $5 \%$ of $\delta^{11} \mathrm{~B}$ fractionation between the melt and residual slab, assuming isotope fractionation factors similar to those for fluids and solids, though the strong B speciation bias in melts would reduce this effect ${ }^{51-53}$. Our calculations suggest the melt might at most be $2 \%$ higher in $\delta^{11} \mathrm{~B}$ than its slab source, given $\mathrm{B}$ elemental and isotopic mass balance.

Slab materials with $\delta^{11} \mathrm{~B}$ between $-1.5 \%$ ond $+6.5 \%$ o best fit the LSB data in this study. The high and variable $\delta^{11} \mathrm{~B}$ in granulite melts documented by our LSB results may partly be inherited from oceanic gabbros before subduction (e.g., ODP Hole 735B oceanic gabbros have high and variable $\delta^{11} \mathrm{~B}$ from $-4.3 \%$ to $+24.9 \%{ }^{28,54}$ ), and this variability may later be reduced and partly homogenized by fluid losses before melting, and metasomatism by amphibolite fluid from deeper in the crust and/or fluids derived from lithospheric serpentinites. The initial melts appear to come from gabbros, which are deeper than basalts and sediments in the slab. Melting or dehydration of shallower slab materials are not evident from the LSB boron and radiogenic isotope data, indicating that the top of the slab was possibly scraped off during subduction initiation, exposing the deeper gabbros \pm diabases to the hot mantle wedge.

Basalt and sediment fluid inputs to the high silica boninite mantle source. The data arrays for the HSB in Fig. 3 differ from those of the LSB in that $\delta^{11} \mathrm{~B}$ is much less variable, ranging only from $-0.2 \%$ to $+1.8 \%$, more similar to values for average altered basalts, and to a lesser extent marine sediments, than to many of the LSB. In Fig. 3 the HSB data are coincident with Layer $2 \mathrm{a}$ and 3 basalts/gabbros, albeit at overall higher $\mathrm{B} / \mathrm{Nb}$ than either of these constituents, or of marine sediments. In Fig. 4a, the HSB appear to plot as an extension of a trend of increasing $\mathrm{Ba}$ enrichment with declining $\mathrm{eHf}_{\mathrm{i}}$, defined by the high $\mathrm{Ba} / \mathrm{Nb}$ LSB 
and the Expedition 352 FAB. However, other mobile elements in the HSB show different systematics (Fig. 4c, d; Supplementary Fig. S2), pointing to the involvement of component(s) other than those responsible for LSB genesis.

The HSB differ from the LSB in that their petrogenesis appears to involve the mixing of at least two distinguishable slab components. One slab endmember is a high Ba slab-melt, such as is evident in the high $\mathrm{Ba} / \mathrm{Nb} \mathrm{LSB} . \varepsilon \mathrm{Hf}_{\mathrm{i}}$ declines as Ba becomes more enriched, suggesting a maximum $\mathrm{Ba} / \mathrm{Nb}$ for this component where $\varepsilon \mathrm{Hf}_{\mathrm{i}}$ reaches its lowest, most "Pacific-like" value. Sr/Nd shows a similar, if more scattered, pattern of increase relative to $\varepsilon \mathrm{Hf}_{\mathrm{i}}$ (Fig. $4 \mathrm{~b}$ ), but plotted versus ${ }^{87} \mathrm{Sr} /{ }^{86} \mathrm{Sr}_{\mathrm{i}}$ the HSB trend to higher $\mathrm{Sr} / \mathrm{Nd}$ and $\mathrm{Sr}$ isotopic ratios from a minimum $\mathrm{Sr} / \mathrm{Nd}$ of $\sim 50$, the median value of our LSB data (Fig. $4 \mathrm{c}$ ). Increases in $\mathrm{B} / \mathrm{Nb}$ and $\mathrm{Ba} / \mathrm{Nb}$ in the $\mathrm{HSB}$ are associated with decreases in $\delta^{11} \mathrm{~B}$ and $\varepsilon \mathrm{Nd}_{\mathrm{i}}$, and with increases in ${ }^{87} \mathrm{Sr}^{86} \mathrm{Sr}_{\mathrm{i}}$, suggesting coherent behavior among B, Ba, Sr and Nd during HSB formation (Fig. 3 and Supplementary Fig. S2). ${ }^{87} \mathrm{Sr} /{ }^{86} \mathrm{Sr}_{\mathrm{i}}$ increases in the HSB occur at nearly constant to declining $\mathrm{La} / \mathrm{Sm}$, while $\mathrm{La} / \mathrm{Sm}$ varies markedly in the LSB at near-constant ${ }^{87} \mathrm{Sr} /{ }^{86} \mathrm{Sr}_{\mathrm{i}}$, consistent with variable melt inputs from a crustal source (Fig. $4 \mathrm{~d}$ ). $\varepsilon \mathrm{Hf}_{\mathrm{i}}$ is uniformly low in the $\mathrm{HSB}$, irrespective of the $\mathrm{B} / \mathrm{Nb}, \mathrm{Ba} / \mathrm{Nb}$, or $\mathrm{Sr}$ and $\mathrm{Nd}$ isotopic variations. This apparent decoupling of $\mathrm{Hf}$ isotopes from other tracers, and the patterns seen in mobile element enrichments and in La/Sm suggest that additional $\mathrm{B}, \mathrm{Ba}$, $\mathrm{Sr}$, and REE inputs to HSB mantle sources may have occurred via hydrous fluids, in which $\mathrm{Hf}$ would be immobile ${ }^{55,56}$. Hydrous fluid inputs will decrease $\mathrm{Hf} / \mathrm{Nd}$, and greater fluid inputs will result in higher degrees of melting, that would be reflected in decreases in $\mathrm{Hf} / \mathrm{Ti}$ and $\mathrm{La} / \mathrm{Yb}$ (Supplementary Fig. S2). Slabderived fluids will also have higher $\mathrm{B} / \mathrm{Nb}$ than their protoliths, consistent with the comparatively high HSB values in Fig. $3 \mathrm{a}$. $\mathrm{eHf}_{\mathrm{i}}$ in the HSB thus appears to reflect the same slab contributor seen in the LSB (i.e., melts from less altered basalt/gabbro), which was likely pervasive in the LSB residuum that was re-melted to produce the HSB. The other, more fluid-mobile tracers reflect new, likely fluid-mediated inputs from different slab contributors.

Bulk mixing calculations based on the HSB data patterns in Fig. 3 indicate that the highest ${ }^{87} \mathrm{Sr}^{8}{ }^{86} \mathrm{Sr}_{\mathrm{i}} \mathrm{HSB}$ sample requires $>10 \%$ sediment involvement (Fig. 3c). At $>5$ wt.\% sediments, $\mathrm{Pb}$ isotopes in the HSB become sediment dominated ${ }^{4}$. Amphibolite fluids (based on the Oman amphibolites) derived from a subducted slab with 5-10 wt.\% sediments should have $\mathrm{Ba} / \mathrm{Sr}$ from 0.26 to $0.32^{34}$, similar to the highest values in the HSB (Fig. 5b). Therefore, an estimate of 5-10 wt.\% sediments involved in the slab inputs to the HSB appears reasonable.

In Fig. $6, \mathrm{Cs} / \mathrm{La}$ is negatively correlated with $\varepsilon \mathrm{Nd}_{\mathrm{i}}$ in the HSB. As such, the highest HSB Cs/La ratio most closely reflects the slab fluid signature (Fig. 6). We have calculated the dehydration temperature of the slab, based on experimental results on marine sediments from Hermann and Rubatto ${ }^{57}$. Our peak temperature estimates are between $780^{\circ} \mathrm{C}$ and $840{ }^{\circ} \mathrm{C}$, assuming that altered basalts and sediments experienced no Cs loss before additions to the HSB mantle source; as such our temperature estimates are likely maximum possible values. These estimates are similar to reported solidus temperature for slab sediments (i.e., $<775 \pm 25^{\circ} \mathrm{C}$ at $2 \mathrm{GPa}$, or $810 \pm 15^{\circ} \mathrm{C}$ at $\left.3 \mathrm{GPa}\right)^{58}$, pointing to overall lower temperature conditions at the plate interface during HSB generation. At $\sim 800^{\circ} \mathrm{C}$, slab dehydration could induce a maximum of $\sim 6 \%$ of $\delta^{11} \mathrm{~B}$ fractionation between the fluid and residual slab, assuming near-neutral fluid $\mathrm{pH}$ values ${ }^{51,52}$. Given the lowest $\mathrm{HSB} \delta^{11} \mathrm{~B}$ value of $\sim-0.2 \%$, the dehydrated slab may have had $\delta^{11} \mathrm{~B}$ as low as $-6 \%$. Bulk mixing calculations suggest that a mixture of 5-10 wt.\% subducted sediments $(B=31.5 \mu \mathrm{g} / \mathrm{g}$; $\left.\delta^{11} \mathrm{~B}=-11.2 \% 0^{45}\right)$ and $90-95$ wt.\% of Oman-like amphibolites $\left(\mathrm{B}=33.3 \mu \mathrm{g} / \mathrm{g} ; \delta^{11} \mathrm{~B}=+3.75 \%{ }^{34,35}\right)$ would have $\delta^{11} \mathrm{~B}$ between

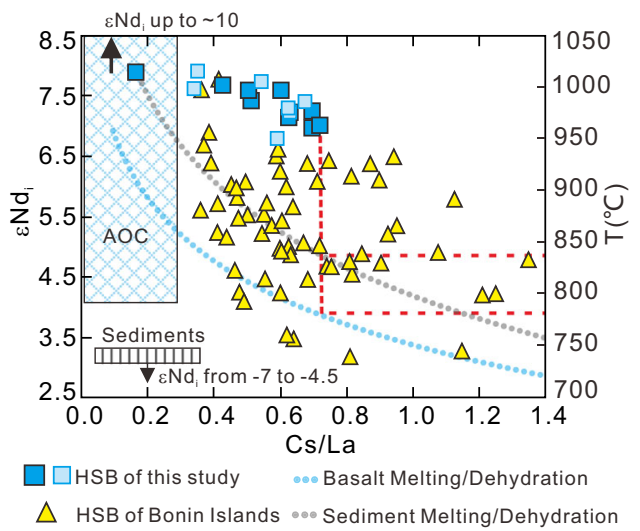

Fig. 6 Elemental ratios and neodymium isotopes characterize slab makeup and temperature during Expedition 352 high-silica boninite generation. $\varepsilon \mathrm{Nd}_{\mathrm{i}}$ (left $y$-axis) vs. $\mathrm{Cs} /$ La diagram for the Expedition 352 and Bonin Islands ${ }^{60}$ high-silica boninite (HSB), Izu-Bonin trench sediments 38 and altered basalts ${ }^{48,67}$. The temperature $\left({ }^{\circ} \mathrm{C}\right.$; right $\mathrm{y}$-axis) versus $\mathrm{Cs} / \mathrm{La}$ paths for sediment (light gray dotted line; calculated after Hermann and Rubatto 57 at 2.5-4.5 GPa) and basalt (light blue dotted line; calculated after Kessel et al. ${ }^{68}$ at $4 \mathrm{GPa}$ with Ocean Drilling Program Site 801 "SuperComponent" as starting material) dehydration/melting are also plotted for comparison. The red dashed lines are used to estimate the slab dehydration/melting temperature during HSB generation of this study according their highest Cs/La ratio. AOC: altered oceanic crust.

$+3.2 \%$ and $+2.3 \%$. These values are higher than our estimated slab component $(<-0.2 \%$, probably as low as $-6 \%)$, and may point to an overestimate of the $\mathrm{B}$ and $\delta^{11} \mathrm{~B}$ in subducted basalts, indicating the subducted basalts may not have been metasomatized by amphibolite- or serpentinite-derived fluids during HSB generation.

\section{Discussion}

Dating of Izu-Bonin FAB and boninites indicate that early IBM magmatism evolved from $\mathrm{FAB}(51.9-51.3 \mathrm{Myr})$ to boninite (51.3-50.3 Myr), and thus from $\approx 0 \%$ to significant additions of slab-derived materials in $<2 \mathrm{Myr}^{7}$. Early radiogenic isotope ${ }^{4}$ and elemental studies ${ }^{12}$ have suggested that LSB mantle sources include melt contributions from oceanic crust, while HSB mantle sources involving contributions from subducting sediments. Our new data for Expedition 352 boninites record details about these early exchanges, which appear to provide insights into physical constraints on the slab input processes and document rapid thermal evolution of the slab during subduction initiation. Higher and more heterogeneous $\delta^{11} \mathrm{~B}$ in the LSB offer evidence the first slab additions came from less altered oceanic crust, most likely lower crustal gabbros. $\mathrm{Sm} / \mathrm{Hf}, \mathrm{Ti} / \mathrm{Hf}^{4,16}$ and $\mathrm{Ba} / \mathrm{Nb}$ ratios in the LSB place melting temperatures on the slab at $900-950^{\circ} \mathrm{C}$. This indicates early heating of the nascent slab due to interactions with upwelling hot mantle. Slab inputs from the upper portions of Pacific plate crust and sediments appear to have begun later, as reflected in the compositions of the overlying HSB. Their higher $\mathrm{B}$ and lower, more uniform $\delta^{11} \mathrm{~B}$ are consistent with slab basalt + sediment contributions most likely via hydrous fluids generated at $\sim 800^{\circ} \mathrm{C}$. This change indicates the start of cooling of the slabmantle interface via refrigeration by early subducted crust and lithosphere. While a small role for B from dehydrated lithospheric serpentinites in the LSB is not entirely precluded by our results, it is clear that unlike in mature volcanic arcs, serpentinite does not play a controlling role in the petrogenesis of either boninite subtype. 

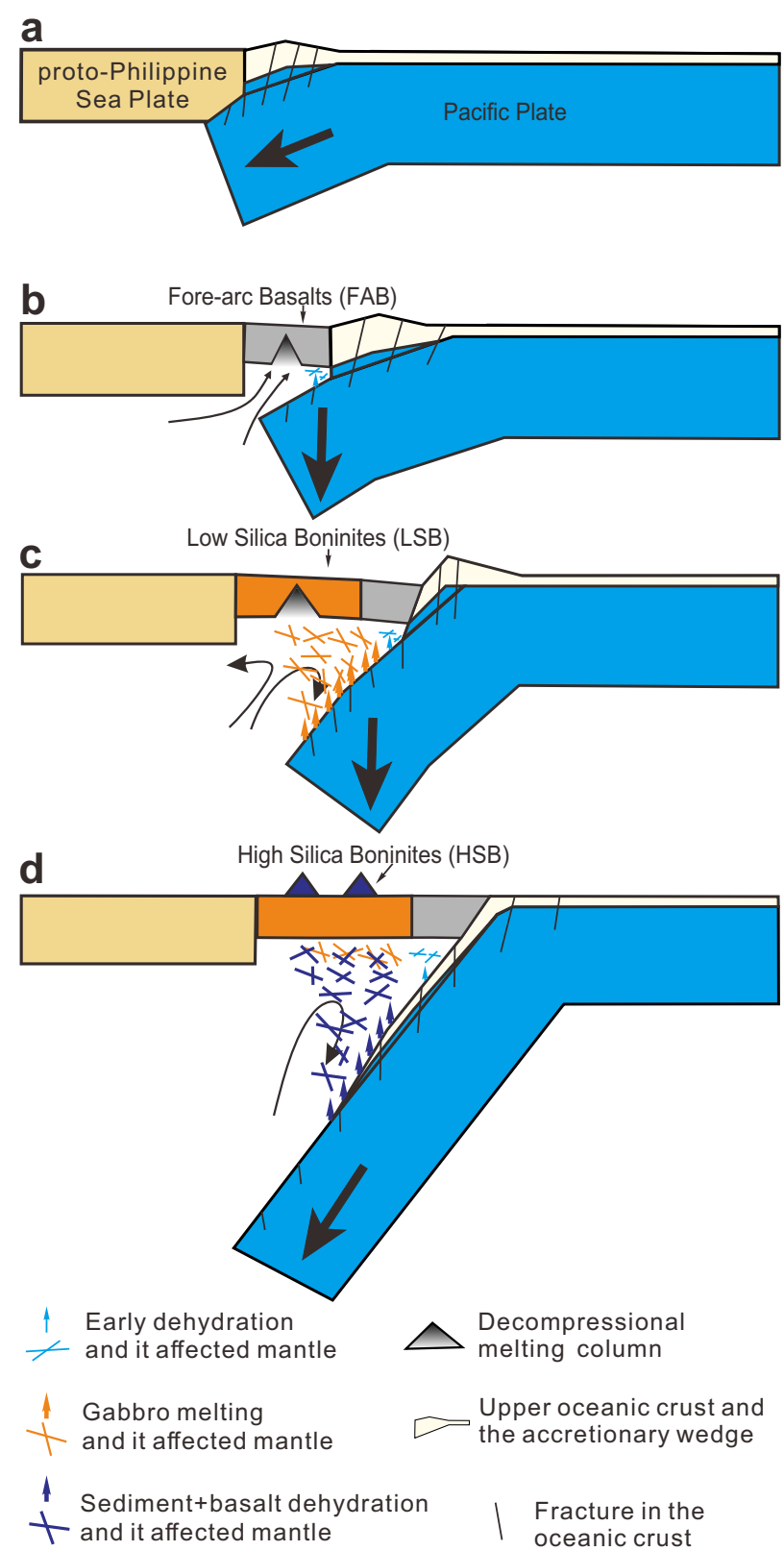

Fig. 7 Cartoons depicting subduction initiation and the slab dehydration/ melting processes. The model starts at a hypothetical transform fault at the boundary between the proto-Philippine Sea Plate and Pacific plate ${ }^{69}$. a Shallow angle convergence of the Pacific plate beneath the proto-Philippine Sea Plate resulted in accretion of Pacific sediments and upper crust. The lower crust experienced higher temperature metasomatism resulting in higher overall $\delta^{11} \mathrm{~B}$. b Decompression melting in response to slab rollback, producing forearc basalt (FAB). c low-silica boninite (LSB) genesis, depleted FAB mantle source metasomatized by lower crust melting components. $\mathbf{d}$ high-silica boninite (HSB) genesis, with an ultra-depleted mantle wedge after LSB extraction further metasomatized by hydrous fluids from a mixed ocean crust source + sediment.

The comparatively rapid temporal changes in slab inputs reflected in the Expedition 352 boninites allow us to place tighter constraints on how the downgoing plate and mantle interact during subduction initiation (Fig. 7). Slow and shallow early convergence apparently disrupted the upper portions of Pacific plate crust, producing a proto-accretionary wedge that included basaltic crustal rocks as well as sediments. Early slab subsidence led to mantle upwelling that triggered the eruption of voluminous $\mathrm{FAB}$, which in their later stages show evidence for some minor slab influence ${ }^{17}$. The subducting portion of the downgoing plate metamorphosed due to burial and contact with hot upwelling mantle, liberating melts and fluids from its leading edge. As subduction-driven mantle convection had not started, a trapped domain of depleted, once-melted mantle (FAB residual mantle) developed near the slab interface, and the fluxing by heterogeneous melts from the gabbroic section of the Pacific slab modified this trapped mantle and triggered LSB magmatism. Increasing slab subsidence rates ultimately resulted in whole-plate subduction, allowing cooler slab crust and lithosphere to penetrate deeper into the mantle. The cooling of the subduction interface likely precluded further crustal melting, but permitted the generation of hydrous fluids from subducting basaltic crust and sediments that further fluxed this melt-modified residual mantle, and resulted in HSB magmatism. As the forearc gradually cooled, the locus of HSB volcanism appears to have moved westward, away from the trench, after $\sim 50 \mathrm{Myr}$, consistent with younger radiometric dates on HSB from the Bonin Islands ( 48-46 Myr) and other localities inboard of the Expedition 352 drillsites ${ }^{59-61}$. Increased sediment subduction combined with a relatively cooler subduction interface leads to the relatively higher $\mathrm{Cs} / \mathrm{La}$ and lower $\varepsilon \mathrm{Nd}_{\mathrm{i}}$ signatures of Bonin Islands HSB (Fig. 6). The geometry and character of HSB magmatism, in which slab fluids trigger mantle melting in a predominantly non-extensional environment, are similar to what is encountered in volcanic $\operatorname{arcs}^{13}$. HSB thus appear to represent "last gasp" forearc magmatic activity, following which the start of subduction-related mantle convection leads to the development of a cooler, stable forearc. Slab cooling leads to low temperature hydrous fluid releases, hydrating the forearc mantle wedge and ultimately producing the "subduction channel" of disaggregated and serpentinized upper and lower plate materials along the plate interface, which is dragged down by the subducting slab to become a high $\delta^{11} \mathrm{~B}$ component in arc volcanic rocks. Ultimately deeper melting of fertile mantle wedge materials well inboard from the trench, triggered via inputs from a deeper slab, produce calc-alkaline arc lavas in the Izu-Bonin system after $44 \mathrm{Myr}^{60}$.

\section{Methods}

Sample selection and preparation. Samples examined in this study were selected from the working halves of cores for Holes U1439A, U1439C, and U1442A, to represent both the natural chemical variability of the IODP Expedition 352 boninites and to reflect overall core stratigraphy. Hole $1439 \mathrm{C}$ best reflects the lithologic variability of Expedition 352 boninite and associated differentiates, comprising nine volcanic units and one basal intrusive unit. The stratigraphy of Hole U1442A is similar to Hole U1439C but simpler, comprising only four volcanic units. Only one volcanic unit (all HSB) was sampled in the three boninite cores recovered from Hole U1439 $\mathrm{A}^{12}$. Therefore, in this study we have investigated Hole U1439C in the greatest detail. The HSB from $<250 \mathrm{mbsf}$ in all three holes are relatively fresh and show similar geochemical variations ${ }^{4,12}$. Two U1439A samples were selected to supplement the HSB samples from Hole U1439C. Four HSB samples, representing intrusive dikes through LSB sequences from $>250 \mathrm{mbsf}$ in Holes U1439C and U1442A, were identified for analysis via our pXRF chemostratigraphy ${ }^{10-12}$, for comparison with the shallower HSB samples. Fresh LSB were only rarely recovered during Expedition 352, so LSB samples from Hole U1442A were selected to supplement those from Hole U1439C. Our samples included fresh boninites selected specifically for this work, and LSB drawn from larger 'POOL' samples, that had been chosen for coordinated post-cruise measurement. The LSB and HSB sample subsets both included some boninitic differentiates, properly termed high-magnesium andesites (HMA). For simplicity of description, we do not discriminate the HMA differentiates from their respective/ parental HSB or LSB. The major and trace element abundances and Sr-Nd-Pb-Hf isotopic ratios of the 'POOL' LSB samples are published in Li et al. ${ }^{4}$.

Below is a brief summary of the analytical methods and quality controls, which include B isotopes for the 'POOL' samples and trace elements and Sr-Nd-Hf-B isotopes for the 'Non-POOL' samples. All 'POOL' samples and a subset of 'NonPOOL' coarse grained samples were leached with $6 \mathrm{M} \mathrm{HCl}$ before sample digestion for $\mathrm{B}$ isotope analyses ${ }^{62}$ to remove seawater-derived B. Leaching experiments done on our fresh samples resulted in no change in their $\delta^{11} \mathrm{~B}$, indicating that these 
samples have not been affected by seawater alteration. All $\delta^{11} \mathrm{~B}$ measurements reported for the 'POOL' samples were conducted on leached powders.

Trace elements. Trace element analyses were performed at Guizhou Tongwei Analytical Technology Co., Ltd. on a Thermal X series 2 ICP-MS equipped with a Cetac ASX-510 AutoSampler. After digestion, samples were dissolved in $3 \mathrm{ml}$ of a $2 \mathrm{M} \mathrm{HNO}_{3}$ stock solution that was then diluted to $4000: 1$ in $2 \% \mathrm{HNO}_{3}$, and spiked with $12 \mathrm{ppb}{ }^{6} \mathrm{Li}, 6 \mathrm{ppb}{ }^{61} \mathrm{Ni}, \mathrm{Rh}$, In and Re, and $4.5 \mathrm{ppb}{ }^{235} \mathrm{U}$ internal standards. The USGS reference material W-2a was used as reference standard and BIR-1, BHVO-2 and several other reference samples were crosschecked. Instrument drift and mass bias were corrected using these internal spikes and external monitors. Based on results for rock standard BIR-1a, the analytical precision for the rare earth elements (REE) and most of the other species analyzed is $\pm 1-5 \%$.

Sr-Nd-Hf isotopes. Sr-Nd-Hf isotopes were analyzed at the Guangzhou Institute of Geochemistry, Chinese Academy of Sciences (GIG-CAS). Sr isotopic ratios were measured on a Thermo Triton TIMS, and ${ }^{87} \mathrm{Sr} /{ }^{86} \mathrm{Sr}$ was corrected for instrumental mass fractionation by normalizing to ${ }^{88} \mathrm{Sr} /{ }^{86} \mathrm{Sr}=8.375209$. The $\mathrm{Sr}$ isotope results are reported relative to SRM 987 of ${ }^{87} \mathrm{Sr} /{ }^{86} \mathrm{~S}=0.710248$. Rock standards BHVO-2 $\left({ }^{87} \mathrm{Sr} /{ }^{86} \mathrm{Sr}=0.703506 \pm 5,2 \mathrm{SE}\right), \mathrm{AGV}-2(0.703976 \pm 7), \mathrm{JB}-3(0.703432 \pm 7)$, and $\mathrm{W}-2 \mathrm{~A}(0.706952 \pm 7)$ were prepared and measured along with the unknowns to monitor the quality of $\mathrm{Sr}$ analyses. We analyzed $\mathrm{Nd}-\mathrm{Hf}$ isotope ratios on a Finnegan Neptune MC-ICPMS. Neodymium and Hf isotope ratios were monitored and corrected for mass bias using the values of ${ }^{146} \mathrm{Nd} /{ }^{144} \mathrm{Nd}=0.7219$ and ${ }^{179} \mathrm{Hf} /$ ${ }^{177} \mathrm{Hf}=0.7325$, respectively. The $\mathrm{Nd}$ isotopic ratios are reported relative to ${ }^{143} \mathrm{Nd} /$ ${ }^{144} \mathrm{Nd}$ of JNdi- $1=0.512115$. The rock standard BHVO-2 was repeatedly analyzed with chemical treatment in separated aliquot for each analysis, yielding a results of ${ }^{143} \mathrm{Nd} /{ }^{144} \mathrm{Nd}=0.512986 \pm 4(1 \mathrm{SD}, n=2)$. Analyses of rock standard JB-3 and $\mathrm{W}-2 \mathrm{~A}$ gave ${ }^{143} \mathrm{Nd} /{ }^{144} \mathrm{Nd}=0.513043 \pm 5$ and $0.512529 \pm 5$ (SE), respectively. The $\mathrm{Hf}$ isotopic ratios are reported relative to ${ }^{176} \mathrm{Hf} /{ }^{177} \mathrm{Hf}$ of JMC $14374=0.282189$ (corresponding to JMC475 of 0.282158). Analysis of rock standard BHVO-2 and BCR-2 yield ${ }^{176} \mathrm{Hf} / 177 \mathrm{Hf}=0.283097 \pm 4$ and $0.282858 \pm 3(\mathrm{SE})$, respectively.

B and B isotopes. B and B isotopes were analyzed at GIG-CAS ${ }^{62,63}$. B concentrations for the 'Non-POOL' sample was measured on a Varian Vista Pro ICPAES, equipped with an HF-resistant Teflon spray chamber and an $\mathrm{Al}_{2} \mathrm{O}_{3}$ injector. $\mathrm{B}$ was measured using the $249.772 \mathrm{~nm}$ spectral line. B-5, JB-2, JB-3 and JR-2 were chemically prepared with the samples and used as external standards for calibrating $\mathrm{B}$ concentrations. The analytical precision for our B concentration measurements was generally better than $5 \%$ (RSD). B isotope measurements were performed using the Finnegan Neptune MC-ICPMS in sample-standard-bracketing (SSB) mode. NIST SRM 951 dissolved in B-free Milli-Q deionized water was used as the bracketing standard, and the results of measured samples were expressed as $\delta^{11} \mathrm{~B}$ relative to SRM $951^{62}$. The internal precision for $\delta^{11} \mathrm{~B}$ was better than $\pm 0.05 \%$ (1SE), and external precision for $\delta^{11} \mathrm{~B}$ is better than $\pm 0.40 \%$ ( $1 \mathrm{SD}$ ) based on our long-term results for SRM 951. The standard reference samples B-5, B-6, JB-2, $\mathrm{AGV}-2$, and JR-2 were repeatedly prepared and analyzed along our unknowns to monitor the quality of the $\mathrm{B}$ isotope measurements. Measured $\delta^{11} \mathrm{~B}$ values for the reference samples were: AGV-2: $-4.36 \pm 0.68 \%$ ( $2 \mathrm{SD}, n=3)$; B-5: $-4.71 \pm 0.49 \%$ o ( $2 \mathrm{SD}, n=9$ ); B-6: $-2.86 \pm 0.62 \%$ ( $2 \mathrm{SD}, n=9$ ); JB-2: $+7.29 \pm 0.60 \%$ ( $2 \mathrm{SD}, n=9$ ); JB-3: $6.74 \pm 0.09 \%$ ( $2 \mathrm{SD}, n=2)$; and JR-2: $3.10 \pm 0.77 \%$ (2 SD, $n=11)$.

\section{Data availability}

The authors declare that the data generated or analyzed during this study are included in this published article and its Supplementary Information files.

Received: 10 October 2019; Accepted: 2 February 2022;

Published online: 22 February 2022

\section{References}

1. Stern, R. J. \& Gerya, T. Subduction initiation in nature and models: A review. Tectonophysics 746, 173-198 (2018).

2. Guilmette, C. et al. Forced subduction initiation recorded in the sole and crust of the Semail Ophiolite of Oman. Nat. Geosci. 11, 688-695 (2018).

3. Keenan, T. E. et al. Rapid conversion of an oceanic spreading center to a subduction zone inferred from high-precision geochronology. Proc. Natl Acad. Sci. USA 113, E7359-E7366 (2016).

4. Li, H. Y. et al. Radiogenic isotopes document the start of subduction in the Western Pacific. Earth Planet. Sci. Lett. 518, 197-210 (2019).

5. Stern, R. J. Subduction initiation: Spontaneous and induced. Earth Planet. Sci. Lett. 226, 275-292 (2004).

6. Zhou, X. et al. Subduction initiation dynamics along a transform fault control trench curvature and ophiolite ages. Geology 46, 607-610 (2018).
7. Reagan, M. K. et al. Forearc ages reveal extensive short-lived and rapid seafloor spreading following subduction initiation. Earth Planet. Sci. Lett. 506, 520-529 (2019).

8. Reagan, M. K., Pearce, J. A., Petronotis, K., Ryan, J. G. \& Expedition 352 Scientists. Izu-Bonin-Mariana Fore Arc. Proc. IODP 352, https://doi.org/ 10.14379/iodp.proc.352.2015 (2015)

9. Pearce, J. A. \& Reagan, M. K. Identification, classification, and interpretation of boninites from Anthropocene to Eoarchean using Si-Mg-Ti systematics. Geosphere 15, 1008-1037 (2019).

10. Ryan, J. G. et al. Application of a handheld X-ray fluorescence spectrometer for real-time, high-density quantitative analysis of drilled igneous rocks and sediments during IODP Expedition 352. Chem. Geol. 451, 55-66 (2017).

11. Shervais, J. W. et al. Magmatic response to subduction initiation: Part I. Forearc basalts of the Izu-Bonin Arc from IODP Expedition 352. Geochem. Geophys. Geosyst. 20, 314-338 (2019).

12. Shervais, J. W. et al. Magmatic response to subduction initiation, Part II: Boninites and related rocks of the Izu-Bonin Arc from IODP Expedition 352. Geochem. Geophys. Geosyst. 22, e2020GC009093 (2021).

13. Reagan, M. K. et al. Subduction initiation and ophiolite crust: New insights from IODP drilling. Int. Geol. Rev. 59, 1439-1450 (2017)

14. Crawford, A. J., Falloon, T. J. \& Green, D. H. in Boninites and Related Rocks (ed. Crawford, A. J.) 1-49 (Unwin Hyman, 1989).

15. Falloon, T. J. \& Danyushevsky, L. V. Melting of refractory mantle at 1.5, 2 and $2.5 \mathrm{GPa}$ under anhydrous and $\mathrm{H} 2 \mathrm{O}$-undersaturated conditions: Implications for the petrogenesis of high-Ca boninites and the influence of subduction components on mantle melting. J. Pet. 41, 257-283 (2000).

16. Pearce, J. A. et al. Boninite and harzburgite from leg 125 (Bonin-Mariana forearc): a case study of magma genesis during the initial stages of subduction. Proc. ODP, Sci. Results 125, 623-659 (1992).

17. Coulthard, D. A. et al. Magma source evolution following subduction initiation: Evidence from the element concentrations, stable isotope ratios, and water contents of volcanic glasses from the Bonin forearc (IODP Expedition 352). Geochem. Geophys. Geosyst. 22, e2020GC009054 (2021).

18. Ryan, J. G. \& Chauvel, C. In Treatise on Geochemistry (2nd, eds Holland, H D. \& Turekian, K. K.) 3, 479-508 (Elsevier, 2014).

19. De Hoog, J. C. M. \& Savov, I. P. in Boron Isotopes: The Fifth Element (eds. Marschall, H. \& Foster, G.) 217-247 (Springer, 2018).

20. Ishikawa, T. \& Tera, F. Two isotopically distinct fluid components involved in the Mariana arc: Evidence from $\mathrm{Nb} / \mathrm{B}$ ratios and $\mathrm{B}, \mathrm{Sr}, \mathrm{Nd}$, and $\mathrm{Pb}$ isotope systematics. Geology 27, 83-86 (1999).

21. Straub, S. M. \& Layne, G. D. The systematics of boron isotopes in Izu arc front volcanic rocks. Earth Planet. Sci. Lett. 198, 25-39 (2002).

22. Ishikawa, T. \& Nakamura, E. Origin of the slab component in arc lavas from across-arc variation of B and Pb isotopes. Nature 370, 205-208 (1994).

23. Cooper, G. F. et al. Variable water input controls evolution of the Lesser Antilles volcanic arc. Nature 582, 525-529 (2020).

24. Stern, R. J. \& Bloomer, S. H. Subduction zone infancy: examples from the Eocene Izu-Bonin-Mariana and Jurassic California arcs. Geol. Soc. Am. Bull. 104, 1621-1636 (1992).

25. Zhou, X. \& Wada, I. Differentiating induced versus spontaneous subduction initiation using thermomechanical models and metamorphic soles. Nat. Commun. 12, 4632 (2021)

26. Palin, R. M. et al. High-grade metamorphism and partial melting of basic and intermediate rocks. J. Metamorph. Geol. 34, 871-892 (2016).

27. McCaig, A. M. et al. No significant boron in the hydrated mantle of most subducting slabs. Nat. Commun. 9, 4602 (2018).

28. Smith, H. J., Spivack, A. J., Staudigel, H. \& Hart, S. R. The boron isotopic composition of altered oceanic crust. Chem. Geol. 126, 119-135 (1995).

29. Ishikawa, T. \& Nakamura, E. Boron isotope geochemistry of the oceanic crust from DSDP/ODP Hole 504B. Geochim. Cosmochim. Acta 56, 1633-1639 (1992)

30. Yamaoka, K. et al. Boron and oxygen isotope systematics for a complete section of oceanic crustal rocks in the Oman ophiolite. Geochim. Cosmochim. Acta 84, 543-559 (2012).

31. Yamaoka, K., Matsukura, S., Ishikawa, T. \& Kawahata, H. Boron isotope systematics of a fossil hydrothermal system from the Troodos ophiolite, Cyprus: Water-rock interactions in the oceanic crust and subseafloor ore deposits. Chem. Geol. 396, 61-73 (2015).

32. Marschall, H. R. et al. The boron and lithium isotopic composition of mid-ocean ridge basalts and the mantle. Geochim. Cosmochim. Acta 207, 102-138 (2017).

33. Pabst, S. et al. The fate of subducted oceanic slabs in the shallow mantle: Insights from boron isotopes and light element composition of metasomatized blueschists from the Mariana forearc. Lithos 132-133, 162-179 (2012).

34. Ishikawa, T., Fujisawa, S., Nagaishi, K. \& Masuda, T. Trace element characteristics of the fluid liberated from amphibolite-facies slab: Inference from the metamorphic sole beneath the Oman ophiolite and implication for boninite genesis. Earth Planet. Sci. Lett. 240, 355-377 (2005).

35. Prigent, C. et al. Transfer of subduction fluids into the deforming mantle wedge during nascent subduction: Evidence from trace elements and boron 
isotopes (Semail ophiolite, Oman). Earth Planet. Sci. Lett. 484, 213-228 (2018).

36. Cai, C., Wiens, D. A., Shen, W. S. \& Eimer, M. Water input into the Mariana subduction zone estimated from ocean-bottom seismic data. Nature 563, 389-392 (2018).

37. Li, H. Y. et al. Molybdenum isotopes unmask slab dehydration and melting beneath the Mariana arc. Nat. Commun. 12, 6015 (2021).

38. Plank, T. in Treatise on Geochemistry (2nd, eds Holland, H. D. \& Turekian, K. K.) Vol. 4, 607-629 (Elsevier, 2014).

39. Ishikawa, T. \& Nakamura, E. Boron isotope systematics of marine sediments. Earth Planet. Sci. Lett. 117, 567-580 (1993).

40. Savov, I. P., Ryan, J. G., D’Antonio, M. \& Fryer, P. Shallow slab fluid release across and along the Mariana arc-basin system: Insights from geochemistry of serpentinized peridotites from the Mariana fore arc. J. Geophys. Res. 112, B09205 (2007).

41. Savov, I. P., Ryan, J. G., D’Antonio, M., Kelley, K. \& Mattie, P. Geochemistry of serpentinized peridotites from the Mariana Forearc Conical Seamount, ODP Leg 125: Implications for the elemental recycling at subduction zones. Geochem. Geophys. Geosyst. 6, Q04J15 (2005).

42. Bebout, G. E., Ryan, J. G. \& Leeman, W. P. B-Be systematics in subductionrelated metamorphic rocks: Characterization of the subducted component. Geochim. Cosmochim. Acta 57, 2227-2237 (1993).

43. Bebout, G. E., Ryan, J. G., Leeman, W. P. \& Bebout, A. E. Fractionation of trace elements by subduction-zone metamorphism - effect of convergentmargin thermal evolution. Earth Planet. Sci. Lett. 171, 63-81 (1999).

44. Menzies, C. et al. Spatial variation of subduction zone fluids during progressive subduction: Insights from Serpentinite Mud Volcanoes. Geochim. et Cosmochim. Acta https://doi.org/10.1016/j.gca.2021.10.030 (2021).

45. Nakano, T. \& Nakamura, E. Boron isotope geochemistry of metasedimentary rocks and tourmalines in a subduction zone metamorphic suite. Phys. Earth Planet. Inter. 127, 233-252 (2001).

46. Hacker, B. R. \& Mosenfelder, J. L. Metamorphism and deformation along the emplacement thrust of the Samail ophiolite, Oman. Earth Planet. Sci. Lett. 144, 435-451 (1996).

47. Connolly, J. A. D. Computation of phase equilibria by linear programming: A tool for geodynamic modeling and its application to subduction zone decarbonation. Earth Planet. Sci. Lett. 236, 524-541 (2005).

48. Kelley, K. A., Plank, T., Ludden, J. \& Staudigel, H. Composition of altered oceanic crust at ODP Sites 801 and 1149. Geochem. Geophys. Geosyst. 4, 8910 (2003).

49. Workman, R. K. \& Hart, S. R. Major and trace element composition of the depleted MORB mantle (DMM). Earth Planet. Sci. Lett. 231, 53-72 (2005).

50. Zhang, W. Q., Liu, C. Z. \& Dick, H. J. B. Evidence for multi-stage melt transport in the lower ocean crust: The Atlantis Bank Gabbroic Massif (IODP Hole U1473A, SW Indian Ridge). J. Petrol. 61, egaa082 (2020).

51. Hervig, R. L. et al. Isotopic and elemental partitioning of boron between hydrous fluid and silicate melt. Am. Mineral. 87, 769-774 (2002)

52. Wunder, B., Meixner, A., Romer, R. L., Wirth, R. \& Heinrich, W. The geochemical cycle of boron: Constraints from boron isotope partitioning experiments between mica and fluid. Lithos 84, 206-216 (2005).

53. Kowalski, P. M. \& Wunder, B. in Boron Isotopes: The Fifth Element (eds Marschall, H. \& Foster, G.) 33-69 (Springer, 2018).

54. Hart, S. R., Blusztajn, J., Dick, H. J. B., Meyer, P. S. \& Muehlenbachs, K. The fingerprint of seawater circulation in a 500-meter section of ocean crust gabbros. Geochim. Cosmochim. Acta 63, 4059-4080 (1999).

55. Pearce, J. A., Kempton, P. D. \& Gill, J. B. Hf-Nd evidence for the origin and distribution of mantle domains in the SW Pacific. Earth Planet. Sci. Lett. 260, 98-114 (2007)

56. Woodhead, J., Stern, R. J., Pearce, J., Hergt, J. \& Vervoort, J. Hf-Nd isotope variation in Mariana Trough basalts: The importance of "ambient mantle" in the interpretation of subduction zone magmas. Geology 40, 539-542 (2012).

57. Hermann, J. \& Rubatto, D. Accessory phase control on the trace element signature of sediment melts in subduction zones. Chem. Geol. 265, 512-526 (2009).

58. Johnson, M. C. \& Plank, T. Dehydration and melting experiments constrain the fate of subducted sediments. Geochem. Geophys. Geosyst. 1, 1007 (1999).

59. Ishizuka, O. et al. Early stages in the evolution of Izu-Bonin arc volcanism New age, chemical, and isotopic constraints. Earth Planet. Sci. Lett. 250, 385-401 (2006).

60. Ishizuka, O., Taylor, R. N., Umino, S. \& Kanayama, K. Geochemical evolution of arc and slab following subduction initiation: A record from the Bonin Islands, Japan. J. Petrol. 61, egaa050 (2020).

61. Li, Y. B. et al. High-Mg adakite and low-Ca boninite from a Bonin fore-arc seamount: Implications for the reaction between slab melts and depleted mantle. J. Pet. 54, 1149-1175 (2013).

62. Li, X. et al. High-precision measurement of B isotopes on low-boron oceanic volcanic rock samples via MC-ICPMS: Evaluating acid leaching effects on boron isotope compositions, and B isotopic variability in depleted oceanic basalts. Chem. Geol. 505, 76-85 (2019).
63. Wei, G. J. et al. Measurement on high-precision boron isotope of silicate materials by a single column purification method and MC-ICP-MS. J. Anal. Spectrom. 28, 606-612 (2013).

64. Salters, V. J. M. \& Stracke, A. Composition of the depleted mantle. Geochem. Geophys. Geosyst. 5, Q05B07 (2004).

65. Boschi, C. et al. Serpentinization of mantle peridotites along an uplifted lithospheric section, Mid Atlantic Ridge at $11^{\circ}$ N. Lithos 178, 3-23 (2013)

66. Staudigel, H., Davies, G. R., Hart, S. R., Marchant, K. M. \& Smith, B. M. Large scale isotopic $\mathrm{Sr}, \mathrm{Nd}$ and $\mathrm{O}$ isotopic anatomy of altered oceanic crust: DSDP/ ODP sites 417/418. Earth Planet. Sci. Lett. 130, 169-185 (1995).

67. Hauff, F., Hoernle, K. \& Schmidt, A. Sr-Nd-Pb composition of Mesozoic Pacific oceanic crust (Site 1149 and 801, ODP Leg 185): Implications for alteration of ocean crust and the input into the Izu-Bonin-Mariana subduction system. Geochem. Geophys. Geosyst. 4, 8913 (2003).

68. Kessel, R., Schmidt, M. W., Ulmer, P. \& Pettke, T. Trace element signature of subduction-zone fluids, melts and supercritical liquids at $120-180 \mathrm{~km}$ depth. Nature 437, 724-727 (2005)

69. Lallemand, S. Philippine Sea Plate inception, evolution, and consumption with special emphasis on the early stages of Izu-Bonin-Mariana subduction. Prog. Earth Planet. Sci. 3, 15 (2016)

\section{Acknowledgements}

All authors thank the International Ocean Discovery Program (IODP) for samples. H.Y.L. and J.G.R. appreciate the contributions of the members of the IODP Exp. 352 Scientific Party as well as the officers and crew, and scientific support staff, on the JOIDES Resolution. H.Y.L., X.L., and Y.G.X. were supported by the National Natural Science Foundation of China (NSFC Project 41922020), the Strategic Priority Research Program of the Chinese Academy of Sciences (Grant No. XDB42020201, XDB18000000) and the Key Special Project for Introduced Talents Team of Southern Marine Science and Engineering Guangdong Laboratory (Guangzhou) (GML2019ZD0202). J.G.R. thanks the USSSP for initial Expedition funding, NSF for grant OCE-1558855, and USF for a UNINexus travel and collaboration award. H.Y.L. thanks Le Zhang, Jinlong Ma, Xuefei Chen and Gangjian Wei for their contributions to the analyses and running of the GIG-CAS laboratories. This is contribution No. IS-3123 from GIGCAS.

\section{Author contributions}

H.Y.L. and J.G.R. conceived and designed the study, comprehensively interpreted the geochemical data and drafted the primary manuscript. X.L. conducted the geochemical analyses. C.Z. conducted the pseudosection calculations. Y.G.X. contributed to improving the interpretation of the data and the writing of the manuscript.

\section{Competing interests}

The authors declare no competing interests.

\section{Additional information}

Supplementary information The online version contains supplementary material available at https://doi.org/10.1038/s41467-022-28637-6.

Correspondence and requests for materials should be addressed to Hong-Yan Li, Xiang Li or Jeffrey G. Ryan.

Peer review information Nature Communications thanks George Cooper, Jan De Hoog and the other, anonymous, reviewer(s) for their contribution to the peer review of this work. Peer reviewer reports are available.

Reprints and permission information is available at http://www.nature.com/reprints

Publisher's note Springer Nature remains neutral with regard to jurisdictional claims in published maps and institutional affiliations.

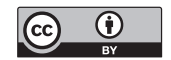

Open Access This article is licensed under a Creative Commons Attribution 4.0 International License, which permits use, sharing, adaptation, distribution and reproduction in any medium or format, as long as you give appropriate credit to the original author(s) and the source, provide a link to the Creative Commons license, and indicate if changes were made. The images or other third party material in this article are included in the article's Creative Commons license, unless indicated otherwise in a credit line to the material. If material is not included in the article's Creative Commons license and your intended use is not permitted by statutory regulation or exceeds the permitted use, you will need to obtain permission directly from the copyright holder. To view a copy of this license, visit http://creativecommons.org/ licenses/by/4.0/.

(C) The Author(s) 2022 